\title{
Author Index Volume 16
}

Agarwal, N. and Steinmetz, R., Sharing Economy: A Systematic

Literature Review

Aggarwal, R., see Anand, A.

Ahmady, R., see Mehralian, G.

Akdoğan, A. A., see Cingöz, A.

Alén-Savikko, A., see Poesche, J.

Alizadeh, Y. and Jetter, A. J., Pathways for Balancing Exploration and Exploitation in Innovations: A Review and Expansion of Ambidexterity Theory

Alkhaldi, A. N. and Kharma, Q. M., Customer's Intention to Adopt Mobile Banking Services: The Moderating Influence of

Demographic Factors

Alpkan, L., see Săg, S.

AlShehri, M. A. R. and Mishra, S., Feature Based Comparison and Selection of SDN Controller

Anand, A., Aggarwal, R. and Singh, O., Using Weibull Distribution for Modeling Bimodal Diffusion Curves: A Naive Framework to Study Product Life Cycle

Arimany-Serrat, N., see Ferrás-Hernández, X.

Armisen-Morell, A., see Ferrás-Hernández, X.

Arnold, C. and Voigt, K.-I., Determinants of Industrial Internet of Things Adoption in German Manufacturing Companies

Aronson, Z. H., Reilly, R. R. and Lynn, G. S., Understanding the Role of Team Member Personal Style in Project Performance: Does the Type of Innovation Matter?

Aronson, Z., Project Success: Exploring the Value of Backing Up Behaviors and How They Can Be Developed in Project-Based Work

Aydin, M. N., see Dilan, E.

Back, P. and Bausch, A., Not If, But How CEOs Affect Product Innovation: A Systematic Review and Research Agenda

Bala Subrahmanya, M. H., see Chandrashekar, D.

Baloch, M. A., Meng, F. and Lodhi, R. N., Information Systems Capabilities and Customer Capital: A Multiple Mediation Model Bausch, A., see Back, P.
16 (2019) 1930002

16 (2019) 1950050

16 (2019) 1950023

16 (2019) 1940004

16 (2019) 1950021

16 (2019) 1950032

16 (2019) 1950037

16 (2019) 1940001

16 (2019) 1950029

16 (2019) 1950050

16 (2019) 1950014

16 (2019) 1950014

16 (2019) 1950038

16 (2019) 1940002

16 (2019) 1950058

16 (2019) 1950039

16 (2019) 1930001

16 (2019) 1950052

16 (2019) 1950022

16 (2019) 1930001 
Bernal, O.-V. and Toro-Jaramilo, I.-D., Organizational Ambidexterity: Exploration and Exploitation

Birgün, S. and Çerkezoğlu, B. T., A Systematic Approach for

Improving the Software Management Process

16 (2019) 1950033

16 (2019) 1940006

Brun, E. C., Understanding a Business Incubator as a Start-Up

Factory: A Value Chain Model Perspective

Calderón-Hernández, G., see Naranjo-Valencia, J.

Çerkezoğlu, B. T., see Birgün, S.

Çeşmeli, M. Ş., see Pençe, İ.

Chanda, U. and Kumar, A., Optimization of EOQ Model for New

Products Under Multi-Stage Adoption Process

Chandrashekar, D., Bala Subrahmanya, M. H., Joshi, K. and Priyadarshi, T., Effect of Innovation on Firm Performance - The

Case of a Technology Intensive Manufacturing Cluster in India

Chavarnakul, T., see Maolikul, S.

Chiaroni, D., see Urbinati, A.

Chiaroni, D., see Urbinati, A.

Chiesa, V., see Urbinati, A.

Chiesa, V., see Urbinati, A.

Chung, D. and Kang, M., Characteristics of Chief Technology Officers and Radical Innovation

Cingöz, A. and Akdoğan, A. A., A Study on Determining the

Relationships Among Corporate Social Responsibility,

Organizational Citizenship Behavior and Ethical Leadership

Cooper, R. G., see Edwards, K.

Cruzara, G., Segatto, A. P. and Freitas, M., The Process of Innovation: An Analysis of the Cloud Computing Role in Allowing a Challenger Company to Innovate, and its Consequences to an Incumbent One

16 (2019) 1950025

16 (2019) 1950056

16 (2019) 1940006

16 (2019) 1940007

16 (2019) 1950015

16 (2019) 1950052

16 (2019) 1950027

16 (2019) 1950011

16 (2019) 1950006

16 (2019) 1950006

16 (2019) 1950011

16 (2019) 1950026

16 (2019) 1940004

16 (2019) 1950048

16 (2019) 1950028

Csuka, S. I., Martos, T., Kapornaky, M., Sallay, V. and Lewis, C. A., Attitudes Toward Technologies of the Near Future: The Role of Technology Readiness in a Hungarian Adult Sample

da Silva, W. V., see Soares de Almeida, C. A.

da Veiga, C. P., see Soares de Almeida, C. A.

Dalvi-Esfahani, M., Shahbazi, H. and Nilashi, M., Moderating Effects of Demographics on Green Information System Adoption

Dayan, H., see Staub, S.

de Aragão Gomes, I. M., see Felizola, M. P. M.

de Kock, I. H., see Marais, R.

Dehghani, M. and Kim, K. J., Past and Present Research on

Wearable Technologies: Bibliometric and Cluster Analyses of

Published Research from 2000 to 2016

Del Corso, J. M., see Soares de Almeida, C. A.

Dilan, E. and Aydin, M. N., An Integrated Framework for Examining Innovation Alignment in Organizations

Duong, C. M., see Nguyen, N. T. M.

16 (2019) 1950046

16 (2019) 1950036

16 (2019) 1950036

16 (2019) 1950008

16 (2019) 1940008

16 (2019) 1950035

16 (2019) 1950055

16 (2019) 1950007

16 (2019) 1950036

16 (2019) 1950039

16 (2019) 1950041 
Edwards, K., Cooper, R. G., Vedsmand, T. and Nardelli, G., Evaluating the Agile-Stage-Gate Hybrid Model: Experiences from Three SME Manufacturing Firms

Elahi, S., see Sareminia, S.

Engin, M. and Gürses, F., Adoption of Hospital Information Systems in Public Hospitals in Turkey: An Analysis with the Unified Theory of Acceptance and Use of Technology Model

Faraj, O. M. M., see Kareem, J. A. H.

Felizola, M. P. M., de Aragão Gomes, I. M. and Prata de Almeida, M.

B. F., Innovation Ecosystem in Sergipe State: The Difficulties Faced by Startups

16 (2019) 1950048

16 (2019) 1950019

16 (2019) 1950043

16 (2019) 1950017

16 (2019) 1950035

Ferrás-Hernández, X., Armisen-Morell, A., Sabata-Alberich, A., Tarrats-Pons, E. and Arimany-Serrat, N., The New Manufacturing: In Search of the Origins of the Next Generation Manufacturing Start-Ups

Franzò, S., see Urbinati, A.

Frattini, F., see Urbinati, A.

Frattini, F., see Urbinati, A.

Freitas, M., see Cruzara, G.

Gaiola de Oliveira Sanches, A., see Lucato, W. C.

Gianotti, E., see Rocha, C.

Gochermann, J. and Nee, I., The Idea Maturity Model - A Dynamic Approach to Evaluate Idea Maturity

Godinho, M. M., see Lopes, L. F.

Grobbelaar, S. S., see Marais, R.

Guderian, C. C., Identifying Emerging Technologies with Smart Patent Indicators: The Example of Smart Houses

Guimaraes, T., Paranjape, K. and Walton, M., An Expanded Model of Success Factors for NPD Performance

Gülsoy, T. and Ustabaş, A., Corporate Sustainability Initiatives in Gender Equality: Organizational Practices Fostering Inclusiveness at Work in an Emerging-Market Context

Gürses, F., see Engin, M.

Hasanzadeh, A., see Sareminia, S.

Itaya, K., see Kato, K.

Ito, S., see Kato, K.

Jang, Y., Entreprenurial Human Capital and Inward Technology Licensing in the Context of New Technology-Based Firms

Jemala, M., Problematic Roadmapping for Companies in Less Developed Regions of Slovakia

Jetter, A. J., see Alizadeh, Y.

Joshi, K., see Chandrashekar, D.

Jovanović, T., Crowdfunding: What Do We Know So Far?

Kalkan, A., see Pençe, İ.

Kang, M., see Chung, D.

Kapornaky, M., see Csuka, S. I.

Kapur, P. K., see Panwar, S.

16 (2019) 1950014

16 (2019) 1950006

16 (2019) 1950011

16 (2019) 1950006

16 (2019) 1950028

16 (2019) 1950049

16 (2019) 1950062

16 (2019) 1950030

16 (2019) 1950034

16 (2019) 1950055

16 (2019) 1950040

16 (2019) 1950054

16 (2019) 1940005

16 (2019) 1950043

16 (2019) 1950019

16 (2019) 1950042

16 (2019) 1950042

16 (2019) 1950053

16 (2019) 1950051

16 (2019) 1950032

16 (2019) 1950052

16 (2019) 1950009

16 (2019) 1940007

16 (2019) 1950026

16 (2019) 1950046

16 (2019) 1950010 
Kareem, J. A. H., Saeed, K. F. A. and Faraj, O. M. M., Maintenance Practices in Poor Uptime of Operating Equipment Toward Dynamic of Business Issues

16 (2019) 1950017

Kato, K., Ito, S. and Itaya, K., Can Accidental Discoveries be Managed? Exploring Key Factors Impacting Idea Generation in RED Sites in Japan

Kauranen, I., see Poesche, J.

Kharma, Q. M., see Alkhaldi, A. N.

Kiatgamolchai, S., see Maolikul, S.

Kim, K. J., see Dehghani, M.

Kim, S. J., Sheikh, N. J. and Stokes, G., Assessment of Arms Import Policies Using a Hierarchical Decision Model and Expert Judgments: Case Study of South Korean Arms Procurement Organizations

Kompella, L., Digital Innovation in the Public Sector: The Role of Embeddedness in Socio-Technical Transitions

Kumar, A., see Chanda, U.

Leelasantitham, A., see Phaosathianphan, N.

Lewis, C. A., see Csuka, S. I.

Lodhi, R. N., see Baloch, M. A.

Logiudice, R., see Lucato, W. C.

Lopes, L. F. and Godinho, M. M., Innovation and Productivity in Services: A Methodological Approach

Lucato, W. C., Gaiola de Oliveira Sanches, A. and Logiudice, R., Proposing a Model for International Technology in Brazil

Lukason, O., see, M.Mõttus

Lynch, R., Towards an Innovation Link between Dynamic Capabilities and Sustainability Strategy: Options for Emerging Market Companies

Lynn, G. S., see Aronson, Z. H.

Majidpour, M., see Mehralian, G.

Mansotra, V., see Singh, J.

Maolikul, S., Chavarnakul, T. and Kiatgamolchai, S., Market Opportunity Analysis in Thailand: Case of Individual Power Sources by Thermoelectric-Generator Technology for Portable Electronics

16 (2019) 1950027

Marais, R., Grobbelaar, S. S. and de Kock, I. H., Healthcare Technology Transfer in Sub-Saharan Africa: An Inductive Approach

Martos, T., see Csuka, S. I.

Matani, B., Shirazi, B. and Soltanzadeh, J., F-MaMcDm: Sustainable Green-Based Hydrogen Production Technology Roadmap Using Fuzzy Multi-Aspect Multi-Criteria Decision-Making

16 (2019) 1950042

16 (2019) 1950021

16 (2019) 1950037

16 (2019) 1950027

16 (2019) 1950007

16 (2019) 1950045

16 (2019) 1950059

16 (2019) 1950015

16 (2019) 1950060

16 (2019) 1950046

16 (2019) 1950022

16 (2019) 1950049

16 (2019) 1950034

16 (2019) 1950049

16 (2019) 1950018

16 (2019) 1940003

16 (2019) 1940002

16 (2019) 1950023

16 (2019) 1950016

16 (2019) 1950055

16 (2019) 1950046

16 (2019) 1950057

Mehralian, G., Ahmady, R., Majidpour, M. and Peiravian, F., Identification of Critical Factors Contributing to International Technological Collaborations: The Case of Pharmaceutical Industry

Meng, F., see Baloch, M. A.

16 (2019) 1950023

16 (2019) 1950022 
Mishra, S., see AlShehri, M. A. R.

16 (2019) 1950029

Montazer, G., see Sareminia, S.

Moretti, F., "Open" Lab? Studying the Implementation of Open Innovation Practices in a University Laboratory

16 (2019) 1950019

16 (2019) 1950012

Mõttus, M., Lukason, O. and Varblane, U., Which Individual Characteristics are Associated with Academic Entrepreneurship? Evidence from Estonia

Muffatto, M., see Sheriff, M.

Naranjo-Valencia, J., Vidal-Patiño, R. and Calderón-Hernández, G., Characterization of Innovation Research Published in Latin American Journals Indexed in WoS

Narcizo, C. F., see Rocha, C.

Nardelli, G., see Edwards, K.

Nart, S., see Staub, S.

Nazaryan, A. N., see Niebuhr, O.

Nee, I., see Gochermann, J.

Nguyen, N. T. M. and Duong, C. M., What Make the Impact of the Financial Crisis on Innovation Different Across European Countries?

16 (2019) 1950018

16 (2019) 1950020

16 (2019) 1950056

16 (2019) 1950062

16 (2019) 1950048

16 (2019) 1940008

16 (2019) 1950013

16 (2019) 1950030

16 (2019) 1950041

Niebuhr, O. and Nazaryan, A. N., Money Talks - But Less Well so over the Mobile Phone? The Persistence of the Telephone Voice in a $4 G$ Technology Setting and the Resulting Implications for

Business Communication and Mobile-Phone Innovation

Nilashi, M., see Dalvi-Esfahani, M.

Nyberg, T., see Poesche, J.

Oturakci, M., New Technology Acceptance Model Based on Innovation Characteristics with AHP-TOPSIS Approach

Panwar, S., Kapur, P. K. and Singh, O., Modeling Technological Substitution by Incorporating Dynamic Adoption Rate

Paranjape, K., see Guimaraes, T.

Peiravian, F., see Mehralian, G.

Pençe, İ., Kalkan, A. and Çeşmeli, M. Ş., Estimation of the Country Ranking Scores on the Global Innovation Index 2016 Using the Artificial Neural Network Method

Phaal, R., see Vinayavekhin, S.

Phaosathianphan, N. and Leelasantitham, A., Understanding the Adoption Factors Influence on the Use of Intelligent Travel Assistant (ITA) for Eco-Tourists: An Extension of the UTAUT

Pihlajarinne, T., see Poesche, J.

Ploykitikoon, P. and Weber, C. M., Knowledge Pathways and

Performance: An Empirical Study of the National Laboratories in a Technology Latecomer Country

16 (2019) 1950013

16 (2019) 1950008

16 (2019) 1950021

16 (2019) 1950047

16 (2019) 1950010

16 (2019) 1950054

16 (2019) 1950023

16 (2019) 1940007

16 (2019) 1950044

16 (2019) 1950060

16 (2019) 1950021

16 (2019) 1950024

Poesche, J., Pihlajarinne, T., Alén-Savikko, A., Nyberg, T. and

Kauranen, I., Decentralized Production: The Need for Social

Norms-Based Intellectual Property?

16 (2019) 1950021

16 (2019) 1950035

16 (2019) 1950052

Priyadarshi, T., see Chandrashekar, D.

Reilly, R. R., see Aronson, Z. H.

16 (2019) 1940002 
Rocha, C., Narcizo, C. F. and Gianotti, E., Internet of Management Artifacts: Internet of Things Architecture for Business Model Renewal

Rocha, L. A., see Soares de Almeida, C. A.

Sabata-Alberich, A., see Ferrás-Hernández, X.

Saeed, K. F. A., see Kareem, J. A. H.

Sağ, S., Sezen, B. and Alpkan, L., Determinants of Open Innovation and their Interrelations

Sallay, V., see Csuka, S. I.

Sareminia, S., Hasanzadeh, A., Elahi, S. and Montazer, G., Developing Technology Roadmapping Combinational Framework by Meta Synthesis Technique

Segatto, A. P., see Cruzara, G.

Sezen, B., see Sağ, S.

Shahbazi, H., see Dalvi-Esfahani, M.

Sheikh, N. J., see Kim, S. J.

Sheriff, M. and Muffatto, M., University Spin-Offs: A New

Framework Integrating Enablers, Stakeholders and Results

Shirazi, B., see Matani, B.

Singh, J. and Mansotra, V., Towards Development of an Integrated Cloud-Computing Adoption Framework - A Case of Indian School Education System

Singh, O., see Panwar, S.

Singh, O., see Anand, A.

Soares de Almeida, C. A., Del Corso, J. M., Rocha, L. A., da Silva, W. V. and da Veiga, C. P., Innovation and Performance: The Impact of Investments in RछD According to the Different Levels of Productivity of Firms

Soderquist, K. E., see Tirabeni, L.

Soltanzadeh, J., see Matani, B.

Staub, S., Nart, S. and Dayan, H., The Role of Supportive Leader in Influencing Intrapreneurship and Innovation: A Study on the Printing Houses in Topkapi, Istanbul

Steinmetz, R., see Agarwal, N.

Stokes, G., see Kim, S. J.

Tarrats-Pons, E., see Ferrás-Hernández, X.

Tirabeni, L. and Soderquist, K. E., Connecting the Dots: Framing Employee-Driven Innovation in Open Innovation Contexts

Toro-Jaramilo, I.-D., see Bernal, O.-V.

Urbinati, A., Chiaroni, D., Chiesa, V., Franzò, S. and Frattini, F., How Incumbents Manage Waves of Disruptive Innovations: An Exploratory Analysis of the Global Music Industry

Urbinati, A., Chiaroni, D., Chiesa, V. and Frattini, F., The Role of Business Model Design in the Diffusion of Innovations: An Analysis of a Sample of Unicorn-Tech Companies

16 (2019) 1950036

16 (2019) 1950031

16 (2019) 1950057

16 (2019) 1940008

16 (2019) 1930002

16 (2019) 1950045

16 (2019) 1950014

16 (2019) 1950031

16 (2019) 1950033

16 (2019) 1950006

Ustabaş, A., see Gülsoy, T.

Varblane, U., see, M.Mõttus

Vedsmand, T., see Edwards, K.

16 (2019) 1950011

16 (2019) 1940005

16 (2019) 1950018

16 (2019) 1950048 
Vidal-Patiño, R., see Naranjo-Valencia, J.

16 (2019) 1950056

Vinayavekhin, S. and Phaal, R., Synchronization in Strategic

Planning: A Roadmapping Framework

16 (2019) 1950044

Voigt, K.-I., see Arnold, C.

16 (2019) 1950038

Walton, M., see Guimaraes, T.

16 (2019) 1950054

Weber, C. M., see Ploykitikoon, P.

16 (2019) 1950024

Yoeruer, H., The Role of Platform Architecture Characteristics in Flexible Decision-Making

16 (2019) 1950061 